\title{
The Effect of $\mathrm{A}_{2 \mathrm{~A}}$ Adenosine Receptor Activation on C-C Chemokine Receptor 7 Expression in Human THP1 Macrophages During Inflammation
}

\author{
Adrienne J. Williams ${ }^{1}$ and Bruce N. Cronstein ${ }^{1,2,3}$ \\ ${ }^{1}$ Division of Translational Medicine, Department of Medicine, New York University School of \\ Medicine, New York, NY 10016, USA \\ ${ }^{2}$ Department of Medicine, New York University School of Medicine, 550 First Avenue, New York, \\ NY 10016, USA
}

\section{Abstract}

C-C chemokine receptor 7 (CCR7) and its chemoattractant agonist CCL21 promote cell migration and expression of pro-inflammatory proteins in an atherogenic environment. Since $\mathrm{A}_{2 \mathrm{~A}}$ adenosine receptor activation reduces migration and inflammatory effects, we examined its effect on CCR7 expression and migration. CCR7 protein expression decreased by about a third in macrophages treated with $\mathrm{A}_{2 \mathrm{~A}}$ receptor agonist CGS $21680(p=0.028, n=7)$ and was reversed with antagonist, although mRNA levels increased twofold $(p=0.001, n=3)$. Furthermore, macrophages treated with CGS 21680 showed a significant decrease in migration $(p=0.0311, n=7)$. These results suggest that $\mathrm{A}_{2 \mathrm{~A}}$ adenosine receptor activation not only modulates CCR7 expression in both normal and inflammatory environments but also regulates macrophage migration to CCR7-specific chemoattractants.

\section{Keywords}

$\mathrm{A}_{2 \mathrm{~A}}$ adenosine receptor; macrophage; chemokine receptor migration

\section{INTRODUCTION}

\begin{abstract}
Atherogenesis occurs when arterial injury leads to a persistent inflammatory responseinflammatory cells respond and migrate to the area, macrophages take up oxidized lowdensity lipoprotein and, in the process, become foam cells, undergo apoptosis, and accumulate around the lesion, forming a growing plaque that undergoes ineffective repair and may calcify, becoming a complex plaque [1-4]. Chemokines and their receptors play a role in atherogenesis and arterial repair by regulating the recruitment and function of proinflammatory and plaque-destabilizing cells [5-7].
\end{abstract}

\footnotetext{
(C) 2011 Springer Science+Business Media, LLC

${ }^{3}$ To whom correspondence should be addressed at Department of Medicine, New York University School of Medicine, 550 First Avenue, New York, NY 10016, USA. Bruce.Cronstein@nyumc.org.
} 
The purine adenosine accumulates during tissue injury or stress and, like chemokines, can modulate immune response and cellular function through its receptor subtype $\mathrm{A}_{2 \mathrm{~A}}$ [8-11]. $\mathrm{A}_{2 \mathrm{~A}}$ adenosine receptor activation suppresses inflammation by regulating cytokine production and prevents atherogenesis by suppressing cell migration and reducing foam cell formation through reverse cholesterol transport [12-17]. The A2A adenosine receptor also modulates chemokine receptor levels; in particular, it downregulates $\mathrm{C}-\mathrm{C}$ chemokine receptor subtype 7 (CCR7) expression and function in $\mathrm{T}$ and dendritic cells [18-20]. The attraction of monocytes and macrophages to CCR7's agonists could be used to prevent atherogenesis - if fewer new macrophages migrate into the atherosclerotic plaque, further arterial injury may be prevented.

We hypothesized that A2A adenosine receptor activation modulates CCR7 macrophage expression and migration. We found that while $\mathrm{A} 2 \mathrm{~A}$ adenosine receptor stimulation increased CCR7 mRNA, it decreased protein expression in both noninflammatory and inflammatory environments. As a result, chemotaxis of cells to CCR7 agonists decreased. We also examined signaling at A2A receptors for regulation of CCR7 receptors and found that, as with other functions, adenosine A2A receptors regulate CCR7 expression by a pathway dependent on PKA and MAPK.

\section{MATERIALS AND METHODS}

\section{Materials}

The selective $A_{2 A}$ receptor agonist CGS21680 and its antagonist ZM 241385 were purchased from Tocris Cookson (Bristol, UK). The selective CCR7 agonists CCL19 and CCL21 and the cytokine IFN $\gamma$ were obtained from R\&D Systems (Minneapolis, MN). Epac agonist 8-pcPT-2'-O-Me-cAMP was purchased from Axxora Diagnostics (San Diego, CA) and PKA inhibitor PKI, corresponding to amino acids 5 through 24, from Promega (Madison, WI). Rac inhibitor 553502 and p38 inhibitor SB202190 were obtained from Calbiochem (San Diego, CA), and Mek inhibitor U0126 from Sigma-Aldrich (St. Louis, MO).

\section{Cell Culture}

Human monocytic THP1 cells were purchased from American Type Culture Collection (Manassas, VA). Cells were grown in RPMI-1640 media supplemented with 10\% FBS, $1 \%$ penicillin and streptomycin, and $1 \%$ L-glutamine (Invitrogen, Carlsbad, CA) at $37^{\circ} \mathrm{C}, 5 \%$ $\mathrm{CO}_{2}$. Cells were differentiated to macrophages by incubation with $25 \mathrm{ng} / \mathrm{mL}$ phorbol 12myristate 13-acetate (Sigma-Aldrich) for $48 \mathrm{~h}$.

\section{RNA Isolation and Real-Time RT-PCR}

THP1 monocytes were differentiated to macrophages (700,000 cells per milliliter), given fresh media, and treated with combinations of CGS21680 (1 $\mu \mathrm{M}$ and $100 \mathrm{nM})$ and ZM241385 $(10 \mu \mathrm{M})$ for $4 \mathrm{~h}$. For inflammatory experiments, cells were pretreated with 500 $\mathrm{U} / \mathrm{mL}$ IFN $\gamma$ for 12 to $16 \mathrm{~h}$. For signaling experiments, cells were pretreated for $1 \mathrm{~h}$ with PKA inhibitor $(10 \mu \mathrm{M}), \mathrm{p} 38$ inhibitor $(10 \mu \mathrm{M})$, Rac inhibitor $(10 \mu \mathrm{M})$, or Mek inhibitor $(10$ $\mu \mathrm{M})$. Media were then removed, and RNA was extracted using Trizol (Invitrogen) according 
to the manufacturer's instructions. Of total RNA, $1.5 \mu \mathrm{g}$ was used from each sample for first-strand, complementary deoxyribonucleic acid synthesis with random hexamer primers using an RNA PCR Core Kit (Applied Biosystems, Foster City, CA).

For quantification by real-time PCR, the following primer pairs were used: CCR7 F: 5'TGACATGCACTCAGCTCTTG-3 R: 5'-AGGTTTTCAGTCCCTGTGAC-3' $\left(60^{\circ} \mathrm{C}, 136\right.$ bp). GAPDH F: 5'-AACATCATCCCTGCCTCTAC-3' R: 5'CCCTCTTGCTGATGCCAAAT- $3^{\prime}\left(58^{\circ} \mathrm{C}, 358 \mathrm{bp}\right)$. PCR product was detected using SYBR Green and the MxPro 3005P from Agilent Technologies (Cedar Creek, TX). Gene expression was quantified to a standard curve and normalized to GAPDH.

\section{Western Blot Analysis}

Monocytes were differentiated to macrophages (1.5 million cells per milliliter), given fresh media, and treated with the appropriate cytokines, agonists, and inhibitors for $48 \mathrm{~h}$. Cells were then lysed using radio-immunoprecipitation assay buffer with protease inhibitor cocktail (Sigma-Aldrich) for $30 \mathrm{~min}$ at $4^{\circ} \mathrm{C}$, centrifuged at 10,000 rpm for $10 \mathrm{~min}$, and the supernatant recovered. Of protein, $35 \mu \mathrm{g}$ was separated by $10 \%$ SDS-PAGE and electrotransferred to nitrocellulose membranes (BioRad, Hercules, CA). Nonspecific antibody binding was blocked with Superblock T20 (Thermo, Rockford, IL) for $4 \mathrm{~h}$ at room temperature. The membrane was incubated with a primary antibody against CCR7 (goat polyclonal from Santa Cruz Biotechnologies, Santa Cruz, CA) overnight at $4^{\circ} \mathrm{C}$ and then incubated with anti-goat secondary antibody conjugated to alkaline phosphatase (Santa Cruz Biotechnologies) for $1 \mathrm{~h}$ at room temperature, after washing with TTBS. Protein bands were visualized using electrochemifluorescence substrate and a Storm Phosphoimager (GE Healthcare). Then, the membrane was stripped and incubated with a primary antibody against beta-actin (mouse monoclonal from Abcam, Cambridge, MA) to be used as an internal, normalizing standard. Band intensity was quantified using Kodak Molecular Imaging software (Eastman Kodak, Rochester, NY).

\section{In Vitro Chemotaxis Cell Migration Assay}

Monocytes were differentiated into macrophages, given fresh media, and pretreated with the appropriate cytokines, agonists, and antagonists for $48 \mathrm{~h}$. Two hundred thousand cells were then gently lifted using rubber scrapers and Dispase (Roche, Mannheim, Germany) and added to 5- $\mu \mathrm{m}$ chamber inserts cells from the QCM Cell Migration Assay Kit (Chemicon, Temecula, CA) with fresh media containing $1 \%$ FBS, $1 \%$ penicillin-streptomycin, and $1 \%$ L-glutamine in RPMI-1640 media (Invitrogen); $300 \mathrm{ng} / \mathrm{mL}$ CCL19 or CCL21 was added to starved media in the lower chamber as a chemoattractant. Cells were then incubated for 24 $\mathrm{h}$, and contents of the lower chamber were detached, stained with fluorescein, and lysed according to the manufacturer's instructions. Migration was quantified using the Victor ${ }^{3} \mathrm{~V}$ Plate Reader (Perkin Elmer).

\section{Statistics}

Data are reported as the mean \pm SEM. Differences between treatment groups were analyzed with Graph-Pad Prism (GraphPad Software, San Diego, CA) using one-way analysis of 
variance followed by Tukey posttest, paired and unpaired Student's $t$ tests. A $p$ value of less than 0.05 was considered statistically significant.

\section{RESULTS}

\section{A $2 A_{A}$ Adenosine Receptor Agonist CGS21680 Increases CCR7 mRNA Expression}

There was a dose-dependent increase in CCR7 message in macrophages following treatment with the adenosine A2A agonist CGS21680 ( $p<0.001 v s$. control, $n=3$ ), and co-treatment with the $\mathrm{A}_{2 \mathrm{~A}}$ antagonist ZM241385 abrogated the increase $p<0.01$ vs. CGS, $n=3$, Fig. 1a).

Cytokines, which are abundant in atherosclerotic lesions, may affect expression of such genes as $\mathrm{A}_{2 \mathrm{~A}}$ adenosine receptor expression in THP1 cells. Indeed, IFN $\gamma$ diminishes both expression and function of $\mathrm{A}_{2 \mathrm{~A}}$ receptors and plays a central role in atherogenesis [13]. We therefore determined whether IFN $\gamma$ altered $\mathrm{A}_{2 \mathrm{~A}}$-mediated increases in CCR7 mRNA. We were surprised to observe that, unlike other adenosine receptor functions, IFN $\gamma$ did not alter adenosine $\mathrm{A}_{2 \mathrm{~A}}$-mediated increase in CCR7 message or the capacity of ZM241385 to reverse that effect ( $p<0.04 v s$. CGS, $n=3$, Fig. 1b).

\section{$\mathrm{A}_{2 \mathrm{~A}}$ Adenosine Receptor Agonist CGS21680 Decreases CCR7 Protein Expression}

Because A2A receptor stimulation increased mRNA for CCR7, we next determined whether $\mathrm{A}_{2 \mathrm{~A}}$ adenosine receptor activation similarly regulated CCR7 protein expression. We were surprised to find that, in contrast to mRNA expression, CCR7 protein levels decreased by about a third ( $p<0.03 v s$. control, $n=7)$, an effect that was reversed by the antagonist $(p<0.05$ vs. CGS, $n=7$, Fig. 2a). Pretreatment with the cytokine IFN $\gamma$ also decreased CCR7 protein levels with CGS21680 treatment ( $p<0.04 v s$. control, $n=3$ ) and reversed with ZM241385 ( $p<0.03$ vs. CGS, $n=3$, Fig. 2b).

\section{CGS21680 Modulates CCR7-Mediated Migration in Normal and Pro-inflammatory Environments}

Prior work has indicated that adenosine $\mathrm{A}_{2 \mathrm{~A}}$ receptor stimulation retards chemotactic migration to CCR7 ligands by dendritic cells, and our studies indicate that adenosine $\mathrm{A}_{2 \mathrm{~A}}$ receptor stimulation diminishes CCR7 expression on THP-1 cells [18]. We therefore determined whether adenosine $\mathrm{A}_{2 \mathrm{~A}}$ receptor stimulation regulates chemotaxis to CCR7 ligands by THP- 1 cells in the absence or presence of inflammation. CGS21680 pretreatment reduced migration by $17 \%$ to CCL21 ( $p<0.03 v s$. control, $n=7$ ) and by a similar amount after IFN $\gamma$ pretreatment ( $p<0.03 v s$. IFN $\gamma, n=7$, Fig. 3). Migration to CCL19, a ligand for CCR7, was also reduced. As with the effects on CCR7 expression, the effects of the adenosine receptor agonist were reversed by the $\mathrm{A}_{2 \mathrm{~A}}$ receptor antagonist ZM241385 ( $p<0.008 v s$. CGS, $n=7$, Fig. 4).

\section{$\mathrm{A}_{2 \mathrm{~A}}$ Adenosine Receptor-Induced Changes in CCR7 Expression Are Blocked with PKA, p38, and Mek Inhibitors}

$\mathrm{A}_{2 \mathrm{~A}}$ adenosine receptors stimulate adenylate cyclase activity and increase cellular cAMP content, which activates Epac and/or PKA, which activate signaling pathways including MAPK and p38 [21, 22]. To probe the signaling pathways involved, we used pharmacologic 
inhibitors of protein kinase A and erk1/2 and p38 MAP kinases and observed their effect on the capacity of adenosine $\mathrm{A}_{2 \mathrm{~A}}$ receptor stimulation to alter mRNA levels for CCR7. We found inhibitors of PKA and Mek, but not a p38MAPK inhibitor or an inhibitor of rac (Fig. $5 \mathrm{a}, \mathrm{b})$. In contrast, $\mathrm{p} 38$ and rac inhibition completely blocked the effect of $\mathrm{A}_{2 \mathrm{~A}}$ receptor stimulation on CCR7 protein expression ( $p<0.05 v s$. CGS with p38 inhibition, $n=4$, Fig. $5 \mathrm{c}$, d).

\section{DISCUSSION}

Since $\mathrm{A}_{2 \mathrm{~A}}$ adenosine receptor stimulation reduces inflammatory and atherogenic effects and CCR7 activation promotes these functions, we hypothesized that $\mathrm{A}_{2 \mathrm{~A}}$ adenosine receptor activation could reduce CCR7 expression and thus modulate macrophage migration to inflamed sites or atherosclerotic plaques. Our results provide very interesting results regarding the effects of $\mathrm{A}_{2 \mathrm{~A}}$ receptor ligation on CCR7 expression. We found that receptor ligation increases CCR7 mRNA by a PKA- and MEK-dependent pathway but diminishes surface expression of the protein by a p38MAPK-, rac-dependent pathway (Fig. 6). Clearly, the resulting reduction in CCR7 chemotactic function results from the diminished receptor expression/function.

Macrophages near or within an atherosclerotic plaque are exposed to inflammatory cytokines like IFN $\gamma$, which diminish $\mathrm{A}_{2 \mathrm{~A}}$ adenosine receptor expression and function and might influence their ability to regulate CCR7 levels [13, 23]. Furthermore, reverse cholesterol transport experiments demonstrate that $\mathrm{A}_{2 \mathrm{~A}}$ adenosine receptor function in macrophages is altered by $\operatorname{IFN} \gamma[12,15,17,24]$. Unlike other adenosine $\mathrm{A}_{2 \mathrm{~A}}$ receptormediated effects, the $\mathrm{A}_{2 \mathrm{~A}}$ receptor-stimulated effects on CCR7 mRNA and protein expression were unaffected by IFN $\gamma$.

The contrast between adenosine receptor-stimulated increases in CCR7 mRNA and decreases in CCR7 protein expression and function were surprising. One explanation for these observations is that chemokine receptor processing and transport via the endoplasmic reticulum and Golgi apparatus may be disrupted, degraded, or downgraded by adenosine $\mathrm{A}_{2 \mathrm{~A}}$ receptor stimulation. Adenosine $\mathrm{A}_{2 \mathrm{~A}}$ receptor stimulation may also increase the rate at which CCR7 receptors are cleared from the surface of the cell, as previously demonstrated for other chemotactic receptors in neutrophils [25-27]. Alternatively, translation of CCR7 message may be blocked by adenosine receptor-stimulated microRNAs; a database search has found some miRNAs with sequence similarity of more than $65 \%$ with CCR7, although they are not located in the $5^{\prime}$ region considered most effective for translational blocking (mirbase.org) [28-31].

To determine a signal transduction pathway between $\mathrm{A}_{2 \mathrm{~A}}$ adenosine receptor activation and CCR7 expression, we tested pharmacologic signal transduction inhibitors corresponding to previously demonstrated adenosine $\mathrm{A}_{2 \mathrm{~A}}$ receptor signaling pathways. $\mathrm{A}_{2 \mathrm{~A}}$ adenosine receptor stimulation can activate either the signaling proteins Epac or PKA [17, 32, 33]. PKA activation may then influence many possible downstream pathways, most commonly Erk with its upstream protein Mek and p38 with its upstream protein Rac [21, 34, 35]. We found PKA inhibition reversed $\mathrm{A}_{2 \mathrm{~A}}$ adenosine receptor-induced changes in CCR7 message, 
while Epac analog treatment failed to mimic expression, indicating a PKA-dependent pathway. Mek inhibition blocked change in CCR7 expression as well, while p38 and Rac inhibition did not affect CCR7 message but did change CCR7 protein expression. These results suggest $\mathrm{A}_{2 \mathrm{~A}}$ adenosine receptor activation in THP1 macrophages leads to MAPK signaling through a PKA-dependent pathway for CCR7 expression.

Although we showed the presence of IFN $\gamma$ did not hinder $\mathrm{A}_{2 \mathrm{~A}}$ adenosine receptor's ability to reduce CCR7 expression and cell migration, the cytokines TNFa and interleukin-1 also affect $\mathrm{A}_{2 \mathrm{~A}}$ adenosine receptor expression but were not examined [13]. A thorough examination of the other two cytokines with CGS21680, or a possible combination of all three, would give a better understanding of the receptor's function in an inflammatory, atherogenic environment.

An increasing body of literature demonstrates that adenosine and its receptors may play a role in the development and regression of atherosclerosis. Prior work demonstrates that adenosine $\mathrm{A}_{2 \mathrm{~A}}$ receptor activation diminishes foam cell formation not only by increasing ABCA1 expression but by increasing its function as well [12, 36-39]. We now provide further evidence that adenosine and its receptors might play a beneficial role in atherosclerosis by inhibiting recruitment of macrophages to atherosclerotic plaques.

\section{ABBREVIATIONS}

$\begin{array}{ll}\text { CAMP } & \text { Cyclic adenosine monophosphate } \\ \text { CCL19 } & \text { C-C chemokine ligand 19 } \\ \text { CCL21 } & \text { C-C chemokine ligand 21 } \\ \text { CCR7 } & \text { C-C chemokine receptor subtype 7 } \\ \text { CGS21680 } & \text { 2-p-(2-carboxyethyl) phenethyllamino-5'- } N \text {-ethylcarboxamido- adenosine } \\ \text { DMSO } & \text { Dimethyl sulfoxide } \\ \text { Epac } & \text { Guanine nucleotide exchange factor activated by cAMP } \\ \text { Erk } & \text { Extracellular signal regulated kinase } \\ \text { FBS } & \text { Fetal bovine serum } \\ \text { GAPDH } & \text { Glyceraldehyde phosphate dehydrogenase } \\ \text { IFN } \gamma & \text { Interferon gamma } \\ \text { MAPK } & \text { Mitogen-activated protein kinase } \\ \text { Mek } & \text { MAP kinase kinase } \\ \text { p38 } & \text { p38 mitogen-activated protein kinase } \\ \text { PCR } & \text { Polymerase chain reaction } \\ \text { PKA } & \text { Protein kinase A } \\ \text { Rac } & \text { Subfamily of Rho GTPases }\end{array}$




$\begin{array}{ll}\text { RNA } & \text { Ribonucleic acid } \\ \text { RPMI-1640 } & \text { Roswell Park Memorial Institute media } \\ \text { SDS-PAGE } & \text { Sodium dodecyl sulfate-polyacrylamide gel electrophoresis } \\ \text { SEM } & \text { Standard error mean } \\ \text { SYBR Green } & N^{\prime}, N^{\prime} \text {-dimethyl-N-[4-[(E)-(3-methyl-1,3-benzothiazol-2- } \\ & \text { ylidene)methyl]-1-phenylquinolin-1-ium-2-yl]-N-propylpropane-1,3- } \\ & \text { diamine } \\ \text { THP1 } & \text { Human acute monocytic leukemia cell line } \\ \text { TNFa } & \text { Tumor necrosis factor alpha } \\ \text { TTBS } & \text { Tween/Tris-buffered saline ZM 241385-4-(2-[7-amino- 2-(2-furyl) } \\ & {[1,2,4] \text { triazolo[2,3-a][1,3,5]triazin-5-ylamino]ethyl)phenol }}\end{array}$

\section{REFERENCES}

1. Lord RS, Bobryshev YV. Hallmarks of atherosclerotic lesion development with special reference to immune inflammatory mechanisms. Cardiovascular Surgery. 2002; 10:405-414. [PubMed: 12359417]

2. Lusis AJ. Atherosclerosis. Nature. 2000; 407:233-241. [PubMed: 11001066]

3. Steinberg D. Atherogenesis in perspective: hypercholesterolemia and inflammation as partners in crime. Nature Medicine. 2002; 8:1211-1217.

4. Takahashi K, Takeya M, Sakashita N. Multifunctional roles of macrophages in the development and progression of atherosclerosis in humans and experimental animals. Medical Electron Microscopy. 2002; 35:179-203. [PubMed: 12658354]

5. Campbell DJ, Kim CH, Butcher EC. Chemokines in the systemic organization of immunity. Immunological Reviews. 2003; 195:58-71. [PubMed: 12969310]

6. Lucas AD, Greaves DR. Atherosclerosis: role of chemokines and macrophages. Expert Reviews in Molecular Medicine. 2001; 3:1-18. [PubMed: 14585150]

7. Zlotnik A, Yoshie O, Nomiyama H. The chemokine and chemokine receptor superfamilies and their molecular evolution. Genome Biology. 2006; 7:243. [PubMed: 17201934]

8. Bours MJ, Swennen EL, Di Virgilio F, Cronstein BN, Dagnelie PC. Adenosine 5'-triphosphate and adenosine as endogenous signaling molecules in immunity and inflammation. Pharmacology \& Therapeutics. 2006; 112:358-404. [PubMed: 16784779]

9. Hasko G, Pacher P, Deitch EA, Vizi ES. Shaping of monocyte and macrophage function by adenosine receptors. Pharmacology \& Therapeutics. 2007; 113:264-275. [PubMed: 17056121]

10. McPherson JA, Barringhaus KG, Bishop GG, Sanders JM, Rieger JM, Hesselbacher SE, Gimple LW, Powers ER, Macdonald T, Sullivan G, et al. Adenosine A(2A) receptor stimulation reduces inflammation and neointimal growth in a murine carotid ligation model. Arteriosclerosis, Thrombosis, and Vascular Biology. 2001; 21:791-796.

11. Fredholm BB. Adenosine, an endogenous distress signal, modulates tissue damage and repair. Cell Death and Differentiation. 2007; 14:1315-1323. [PubMed: 17396131]

12. Bingham TC, Fisher EA, Parathath S, Reiss AB, Chan ES, Cronstein BN. A2A adenosine receptor stimulation decreases foam cell formation by enhancing ABCA1-dependent cholesterol efflux. Journal of Leukocyte Biology. 2010; 87:683-690. [PubMed: 20089670]

13. Khoa ND, Montesinos MC, Reiss AB, Delano D, Awadallah N, Cronstein BN. Inflammatory cytokines regulate function and expression of adenosine $\mathrm{A}(2 \mathrm{~A})$ receptors in human monocytic THP-1 cells. Journal of Immunology. 2001; 167:4026-4032. 
14. Link AA, Kino T, Worth JA, McGuire JL, Crane ML, Chrousos GP, Wilder RL, Elenkov IJ. Ligand-activation of the adenosine A2a receptors inhibits IL-12 production by human monocytes. Journal of Immunology. 2000; 164:436-442.

15. Reiss AB, Awadallah NW, Malhotra S, Montesinos MC, Chan ES, Javitt NB, Cronstein BN. Immune complexes and IFN-gamma decrease cholesterol 27-hydroxylase in human arterial endothelium and macrophages. Journal of Lipid Research. 2001; 42:1913-1922. [PubMed: 11714861]

16. Thiel M, Chouker A. Acting via A2 receptors, adenosine inhibits the production of tumor necrosis factor-alpha of endotoxin-stimulated human polymorphonuclear leukocytes. The Journal of Laboratory and Clinical Medicine. 1995; 126:275-282. [PubMed: 7665975]

17. Block, ET. Interferon gamma inhibits adenosine A2A receptor function in hepatic stellate cells by downregulating expression of adenylyl cyclase in a STAT1-dependent manner. New York: New York University Department of Basic Medical Sciences; 2009.

18. Hofer S, Ivarsson L, Stoitzner P, Auffinger M, Rainer C, Romani N, Heufler C. Adenosine slows migration of dendritic cells but does not affect other aspects of dendritic cell maturation. The Journal of Investigative Dermatology. 2003; 121:300-307. [PubMed: 12880422]

19. Sun J, Zhang Y, Yang M, Zhang Y, Xie Q, Li Z, Dong Z, Yang Y, Deng B, Feng A, et al. Hypoxia induces T-cell apoptosis by inhibiting chemokine $\mathrm{C}$ receptor 7 expression: the role of adenosine receptor A(2). Cellular \& Molecular Immunology. 2010; 7:77-82. [PubMed: 20029460]

20. Zhang H, Park Y, Wu J, Chen X, Lee S, Yang J, Dellsperger KC, Zhang C. Role of TNF-alpha in vascular dysfunction. Clinical Science (London). 2009; 116:219-230.

21. Fredholm BB, Chern Y, Franco R, Sitkovsky M. Aspects of the general biology of adenosine A2A signaling. Progress in Neurobiology. 2007; 83:263-276. [PubMed: 17804147]

22. Schulte G, Fredholm BB. Signalling from adenosine receptors to mitogen-activated protein kinases. Cellular Signalling. 2003; 15:813-827. [PubMed: 12834807]

23. Nguyen DK, Montesinos MC, Williams AJ, Kelly M, Cronstein BN. Th1 cytokines regulate adenosine receptors and their downstream signaling elements in human microvascular endothelial cells. Journal of Immunology. 2003; 171:3991-3998.

24. Reiss AB, Carsons SE, Anwar K, Rao S, Edelman SD, Zhang H, Fernandez P, Cronstein BN, Chan ES. Atheroprotective effects of methotrexate on reverse cholesterol transport proteins and foam cell transformation in human THP-1 monocyte/macrophages. Arthritis and Rheumatism. 2008; 58:3675-3683. [PubMed: 19035488]

25. Cronstein BN, Haines KA, Kolasinski S, Reibman J. Gs linked receptors (Beta-adrenergic and adenosine A2) uncouple chemoattractant receptors from $\mathrm{G}$ proteins. Clinical Research. 1991; 39:343A.

26. Cronstein BN, Haines KA, Kolasinski S, Reibman J. Occupancy of G alpha s-linked receptors uncouples chemo-attractant receptors from their stimulus-transduction mechanisms in the neutrophil. Blood. 1992; 80:1052-1057. [PubMed: 1323344]

27. Cronstein BN, Rose FR, Pugliese C. Adenosine, a cytoprotective autocoid: effects of adenosine on neutrophil plasma membrane viscosity and chemoattractant receptor display. Biochimica et Biophysica Acta. 1989; 987:176-180. [PubMed: 2574995]

28. The microRNA registry. [mirbase.org].

29. Hawkins PG, Morris KV. RNA and transcriptional modulation of gene expression. Cell Cycle. 2008; 7:602-607. [PubMed: 18256543]

30. Maziere P, Enright AJ. Prediction of microRNA targets. Drug Discovery Today. 2007; 12:452458. [PubMed: 17532529]

31. Williams AE. Functional aspects of animal microRNAs. Cellular and Molecular Life Sciences. 2008; 65:545-562. [PubMed: 17965831]

32. Bos JL. Epac proteins: multi-purpose cAMP targets. Trends in Biochemical Sciences. 2006; 31:680-686. [PubMed: 17084085]

33. Wolff J, Londos C, Cooper DM. Adenosine receptors and the regulation of adenylate cyclase. Advances in Cyclic Nucleotide Research. 1981; 14:199-214. [PubMed: 6269379]

34. Che J, Chan ES, Cronstein BN. Adenosine A2A receptor occupancy stimulates collagen expression by hepatic stellate cells via pathways involving protein kinase A, Src, and extracellular signal- 
regulated kinases 1/2 signaling cascade or p38 mitogen-activated protein kinase signaling pathway. Molecular Pharmacology. 2007; 72:1626-1636. [PubMed: 17872970]

35. Hasko G, Linden J, Cronstein B, Pacher P. Adenosine receptors: therapeutic aspects for inflammatory and immune diseases. Nature Reviews. 2008; 7:759-770.

36. Reiss AB, Anwar K, Merrill JT, Chan ES, Awadallah NW, Cronstein BN, Michael Belmont H, Belilos E, Rosenblum G, Belostocki K, et al. Plasma from systemic lupus patients compromises cholesterol homeostasis: a potential mechanism linking autoimmunity to atherosclerotic cardiovascular disease. Rheumatology International. 2010; 30:591-598. [PubMed: 19547978]

37. Reiss AB, Patel CA, Rahman MM, Chan ES, Hasneen K, Montesinos MC, Trachman JD, Cronstein BN. Interferon-gamma impedes reverse cholesterol transport and promotes foam cell transformation in THP-1 human monocytes/macrophages. Medical Science Monitor. 2004; 10:BR420-BR425. [PubMed: 15507847]

38. Reiss AB, Rahman MM, Chan ES, Montesinos MC, Awadallah NW, Cronstein BN. Adenosine A2A receptor occupancy stimulates expression of proteins involved in reverse cholesterol transport and inhibits foam cell formation in macrophages. Journal of Leukocyte Biology. 2004; 76:727-734. [PubMed: 15197231]

39. Reiss AB, Wan DW, Anwar K, Merrill JT, Wirkowski PA, Shah N, Cronstein BN, Chan ES, Carsons SE. CD36 scavenger receptor expression in THP-1 human monocytes in the presence of lupus plasma: linking autoimmunity and atherosclerosis. Experimental Biology and Medicine (Maywood). 2009; 234:354-360. 


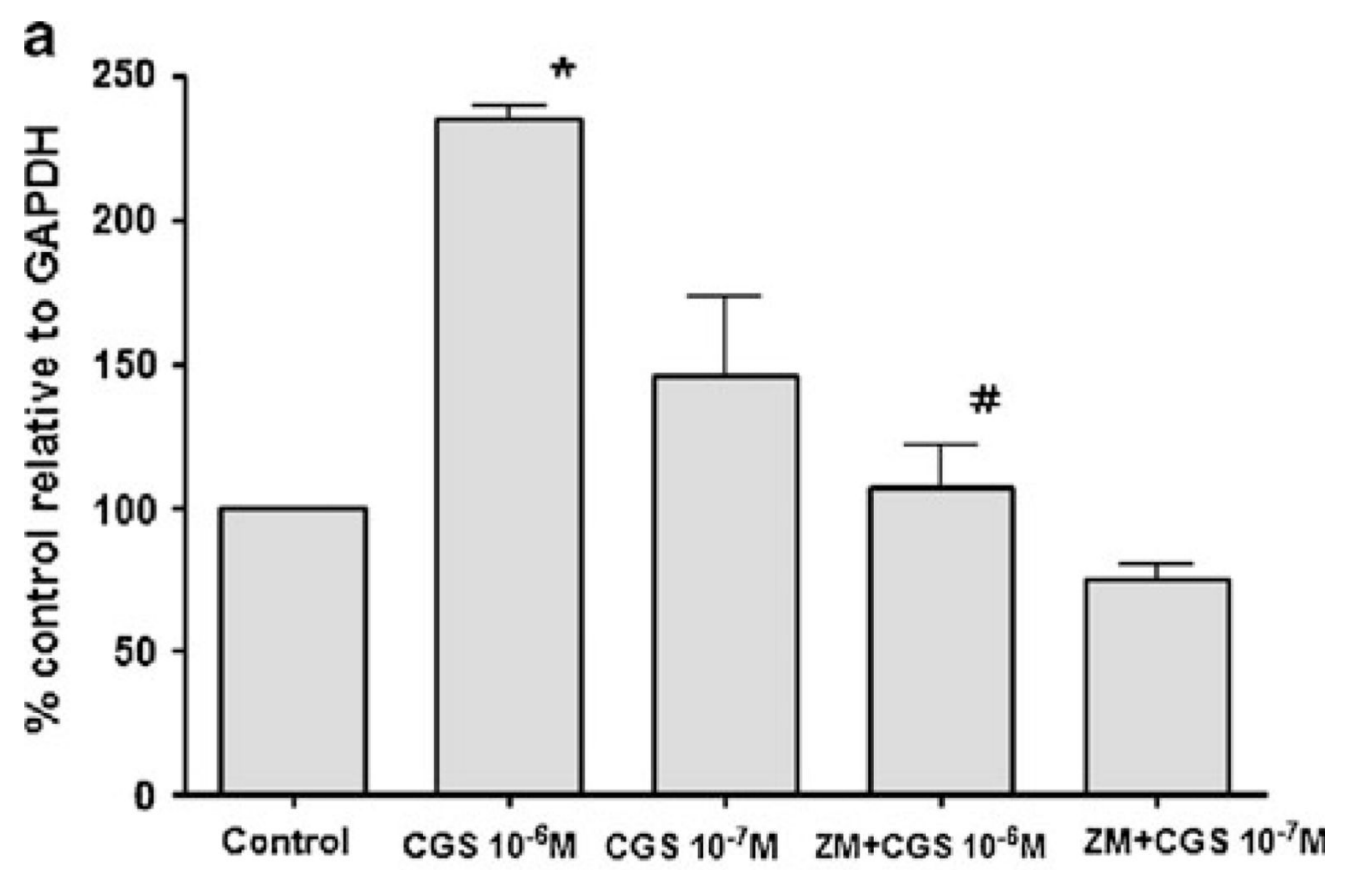

b

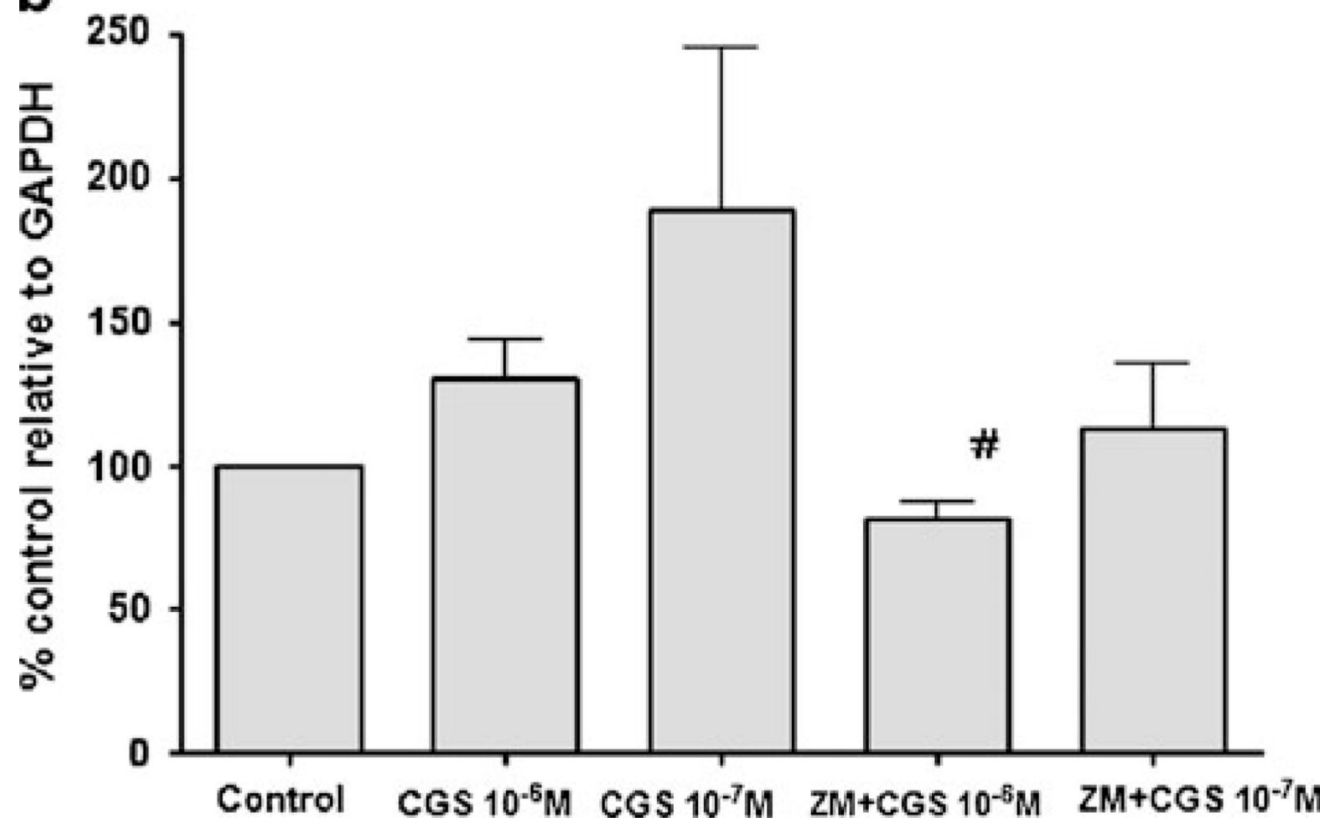

Fig. 1.

$\mathrm{A}_{2 \mathrm{~A}}$ adenosine receptor agonist CGS21680 increases CCR7 mRNA expression and is reversed with antagonist ZM241385 in THP1 macrophages. Messenger RNA isolated from cells pretreated overnight in a regular media conditions or $\mathbf{b}$ IFN $\gamma(500 \mathrm{U} / \mathrm{mL})$ and then treated with combinations of CGS21680 $\left(10^{-6} \mathrm{M}\right.$ and $\left.10^{-7} \mathrm{M}\right), \mathrm{ZM} 241385\left(10^{-5} \mathrm{M}\right)$, and DMSO as a negative control for $4 \mathrm{~h}$ and were subjected to real-time RT-PCR using specific primers. The expression level was quantified using real-time PCR and normalized to GAPDH. Data shown are the means \pm SEM of the percentages of control from three 
independent experiments. a $v s$. Control, ${ }^{*} p=0.001 ; v s$. CGS, $\# p=0.01 ; \mathbf{b} v s$. CGS, $\# p=0.0382$. 


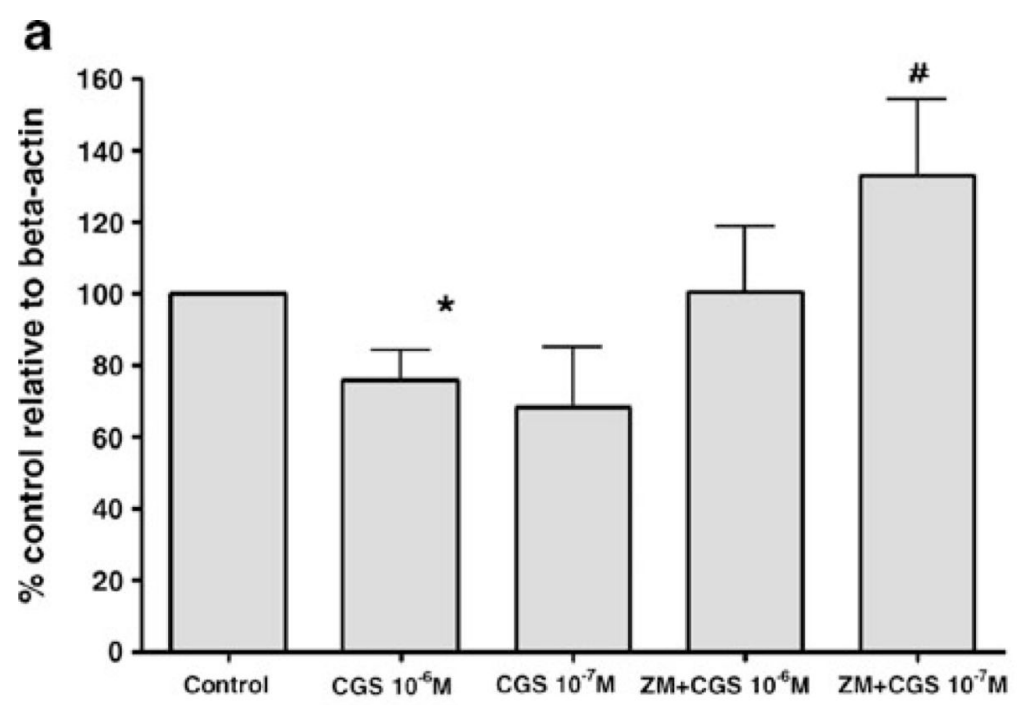

b

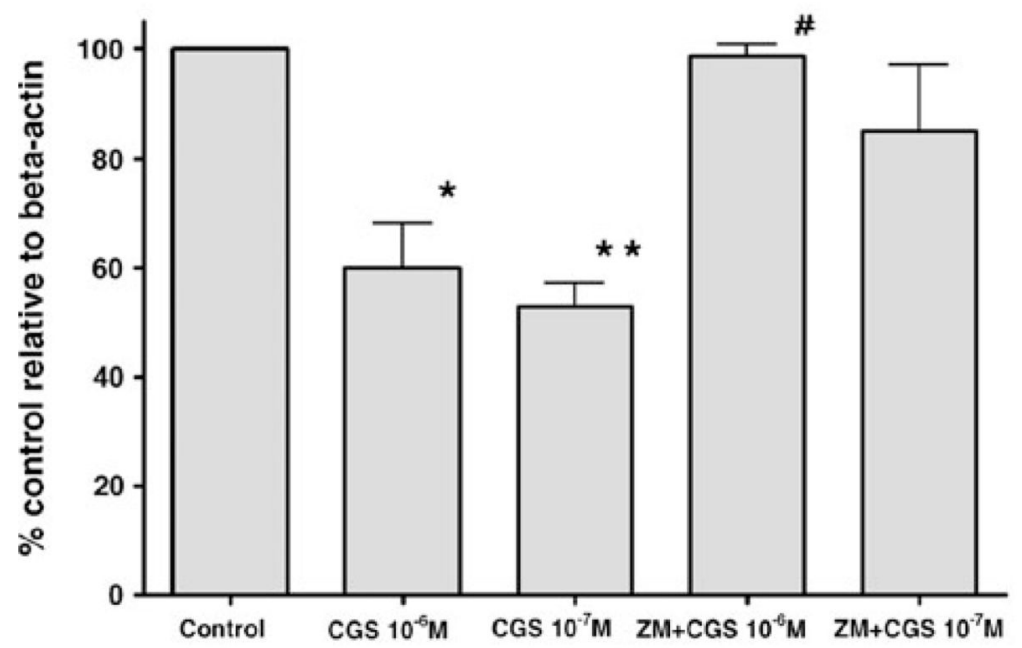

C

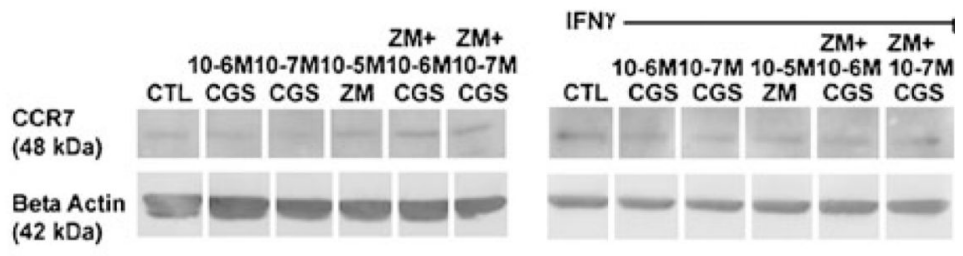

Fig. 2.

$\mathrm{A}_{2 \mathrm{~A}}$ adenosine receptor agonist CGS21680 decreases CCR7 protein expression and is reversed with antagonist ZM241385 in THP1 macrophages. Cells pretreated overnight in a regular media conditions or $\mathbf{b} \operatorname{IFN} \gamma(500 \mathrm{U} / \mathrm{mL})$ and then treated with combinations of CGS21680 $\left(10^{-6} \mathrm{M}\right.$ and $\left.10^{-7} \mathrm{M}\right)$, ZM241385 $\left(10^{-5} \mathrm{M}\right)$, and DMSO as a negative control for $48 \mathrm{~h}$ had $35 \mu \mathrm{g}$ of their protein lysate analyzed with SDS-PAGE and immunoblotting. c Representative immunoblots. The expression level was quantified using Kodak Image Analysis software and normalized to beta-actin. Data shown are the means \pm SEM of the 
percentages of control from a seven blots and $\mathbf{b}$ three blots. a vs. Control, * $p=0.028 ; v s$. CGS, $\# p=0.0432 ; \mathbf{b} v s$. Control, ${ }^{*} p=0.0386, * * p=0.0085 ; v s$. CGS, $\# p=0.0234$. 

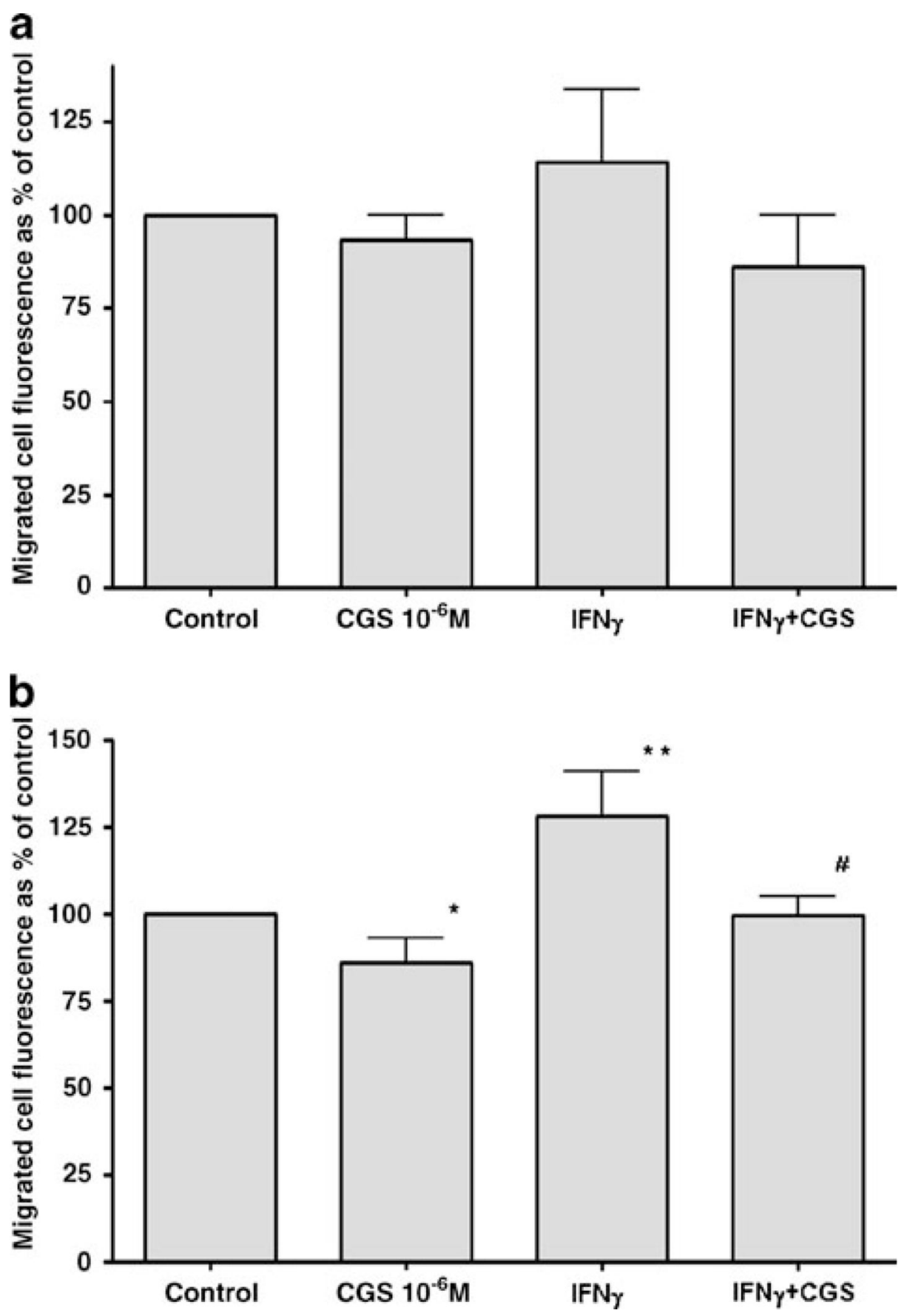

Fig. 3.

CGS21680 treatment with pro-inflammatory cytokines decreases THP1 macrophage migration to CCR7 agonists. Cells were pretreated overnight with IFN $\gamma(500 \mathrm{U} / \mathrm{mL})$ or $\mathrm{TNFa}(10 \mathrm{ng} / \mathrm{mL})$ and then with CGS21680 $\left(10^{-6} \mathrm{M}\right)$ or DMSO as a negative control for 48 h. Cells were then lifted, added in suspension to $5-\mu \mathrm{m}$ upper chamber inserts, and migrated to a lower chamber with a CCL19 $(300 \mathrm{ng} / \mathrm{mL})$ or b CCL21 $(300 \mathrm{ng} / \mathrm{mL})$ for $24 \mathrm{~h}$.

Migration was quantified using fluorescein labeling of cells. Data shown are the means 
\pm SEM of the percentages of three independent experiments with CCL19 and six with CCL21. vs. Control, $* p=0.0311, * * p=0.0389, * * * p=0.0196$. vs. IFN $\gamma, \# p=0.0273$. 


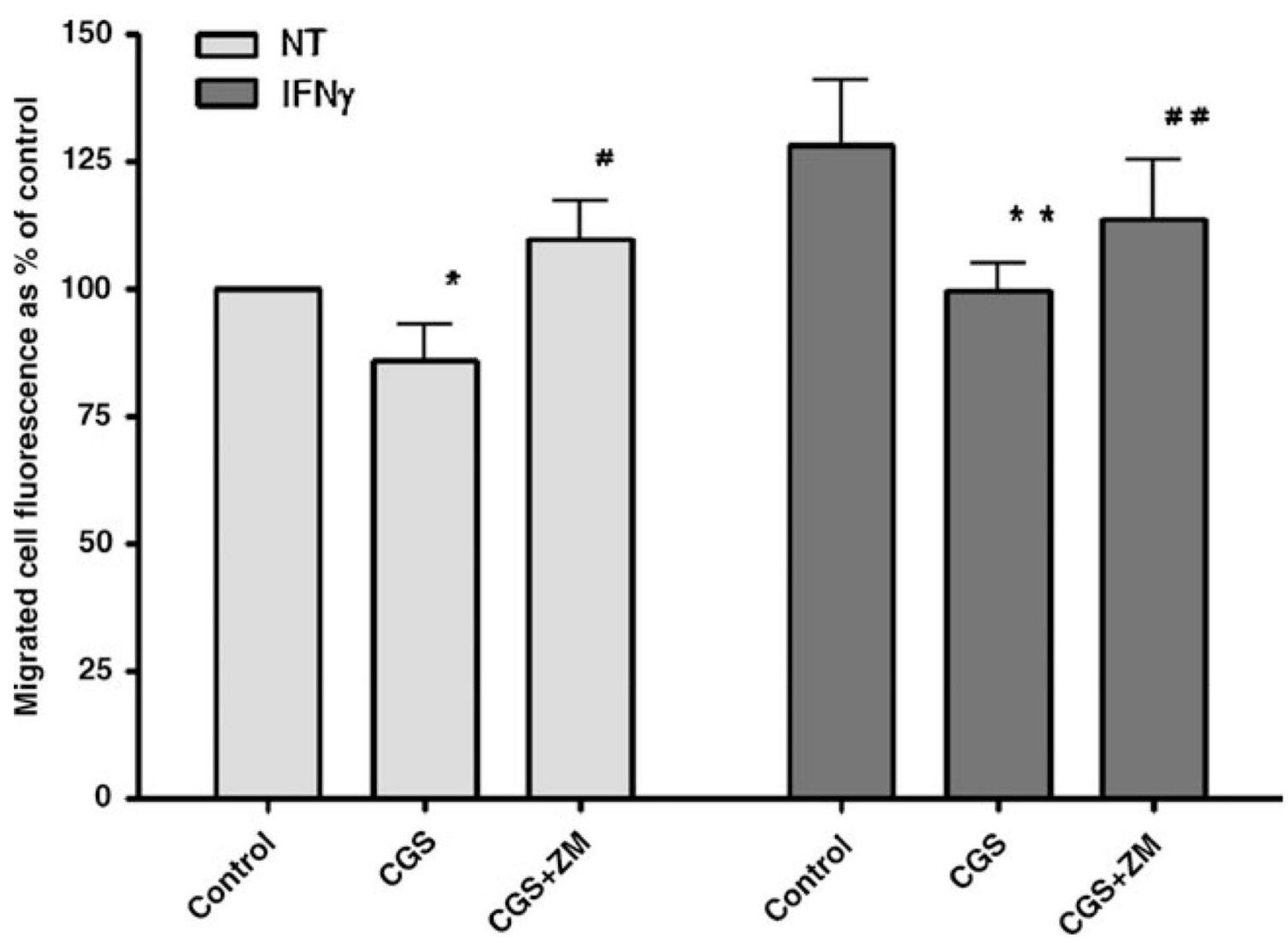

Fig. 4.

CGS21680 treatment with and without IFN $\gamma$ decreases THP1 macrophage migration to CCR7 agonists and is reversed with antagonist ZM241385. Cells were first pretreated overnight with IFN $\gamma(500 \mathrm{U} / \mathrm{mL})$ or TNFa $(10 \mathrm{ng} / \mathrm{mL})$ and then with combinations of CGS21680 $\left(10^{-6} \mathrm{M}\right)$, ZM241385 $\left(10^{-5} \mathrm{M}\right)$, or DMSO as a negative control for $48 \mathrm{~h}$. Cells were then lifted, added in suspension to 5 - $\mu \mathrm{m}$ upper chamber inserts, and migrated to a lower chamber with CCL21 (300 ng/mL) for $24 \mathrm{~h}$. Migration was quantified using fluorescein labeling of cells. Data shown are the means \pm SEM of the percentages of six independent experiments-three with ZM. vs. Control, ${ }^{*} p=0.0311$, ${ }^{* *} p=0.0273$. vs. CGS, $\# p=0.0078, \# \# p=0.125$. 
a

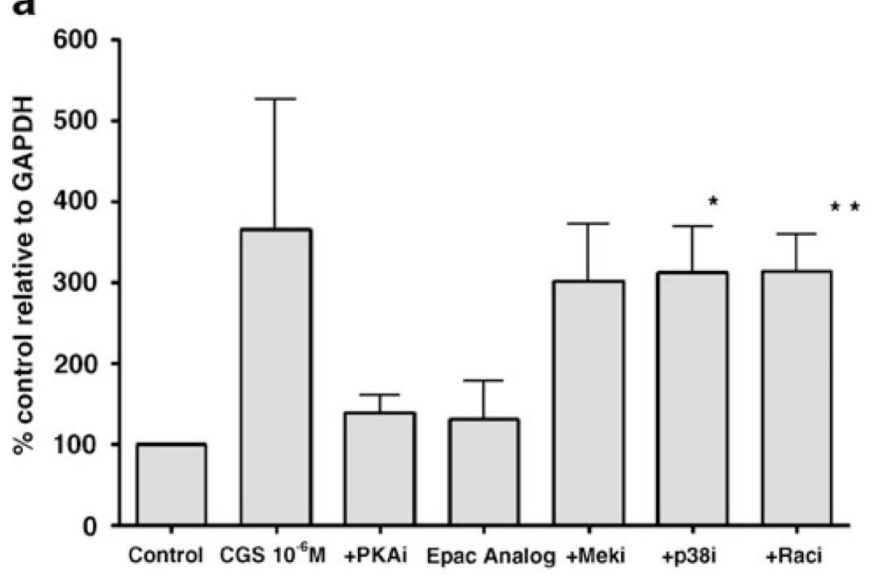

b

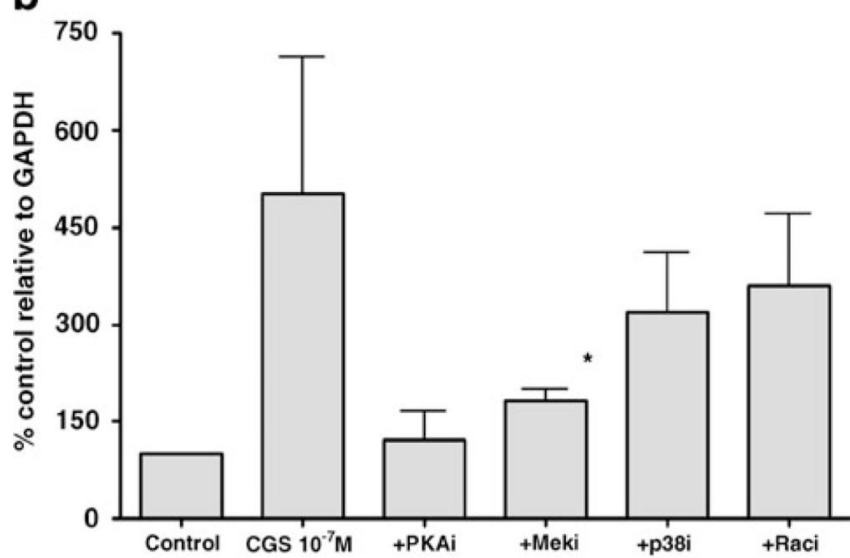

e

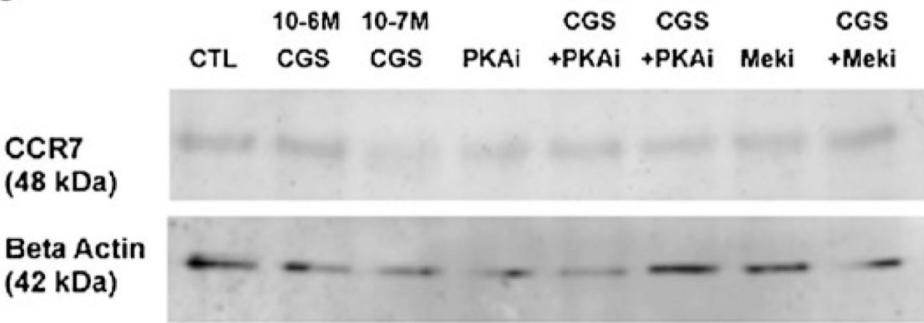

C

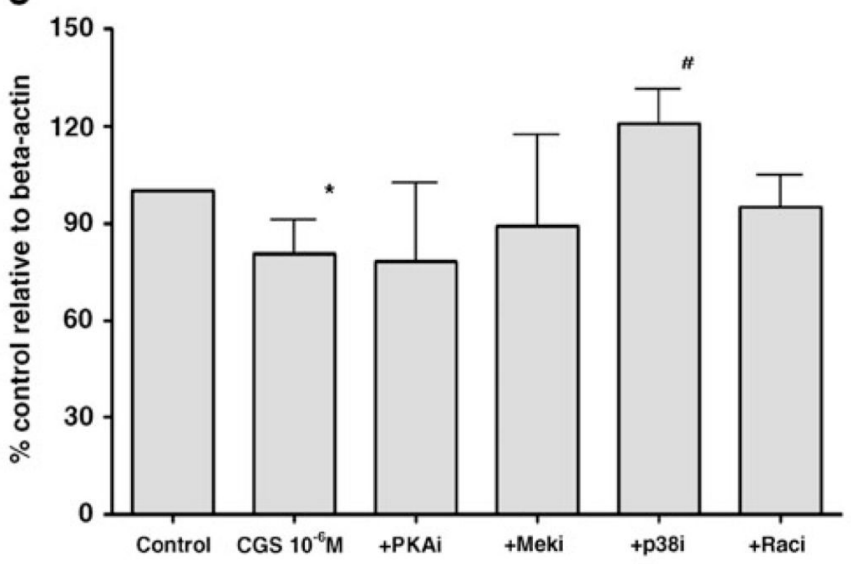

d

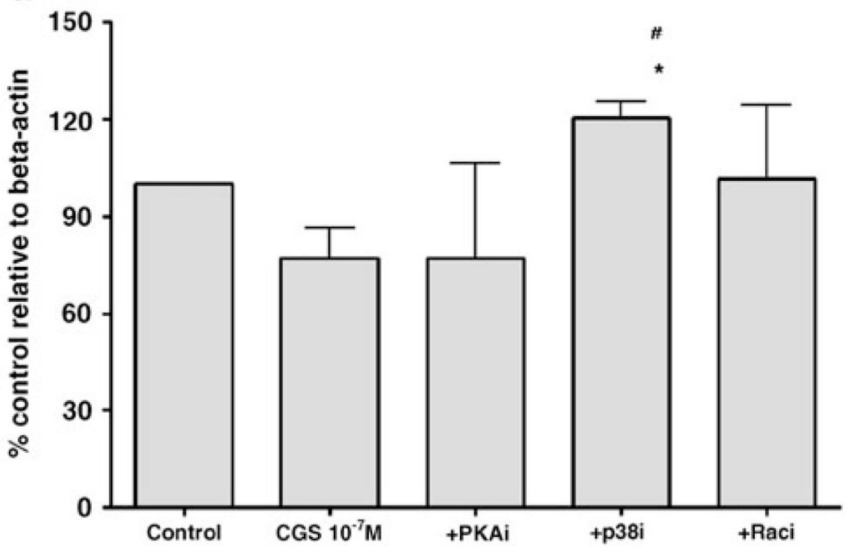

Fig. 5.

$\mathrm{A}_{2 \mathrm{~A}}$ adenosine receptor-induced increase of CCR7 mRNA expression and decrease of CCR7 protein expression in THP1 macrophages can be reversed with PKA, p38, and Mek inhibitors. Cells were treated with combinations of $\mathbf{a} 10^{-6} \mathrm{M}$ or b $10^{-7} \mathrm{M}$ CGS21680 with p38i $(10 \mu \mathrm{M})$, PKAi $(10 \mu \mathrm{M})$, Meki $(10 \mu \mathrm{M})$, Raci $(10 \mu \mathrm{M})$, Epac analog $(10 \mu \mathrm{M})$, and DMSO as a negative control for $4 \mathrm{~h}$, and the messenger RNA collected and subjected to real-time RT-PCR using specific primers. The expression level was quantified using realtime PCR and normalized to GAPDH. Data shown are the means \pm SEM of the percentages of control from three independent experiments. Cells were also treated with combinations of c $10^{-6} \mathrm{M}$ or $\mathbf{d} 10^{-7} \mathrm{M}$ CGS21680 and inhibitors for $48 \mathrm{~h}$ and had $35 \mu \mathrm{g}$ of their cell lysate analyzed with SDS-PAGE and immunoblotting. e Representative immunoblots. The 
expression level was quantified using Kodak Image Analysis software and normalized to beta-actin. Data shown are the means \pm SEM of the percentages of control from three to four blots. a vs. Control, ${ }^{*} p=0.065,{ }^{*} p=0.0416 ; \mathbf{b}$ vs. Control, ${ }^{*} p=0.043 ; \mathbf{c} v s$. Control, $* p=0.038 ; v s$. CGS, $\# p=0.0504 ; \mathbf{d} v s$. Control, ${ }^{*} p=0.0581 ; v s$. CGS, $\# p=0.0204$. 


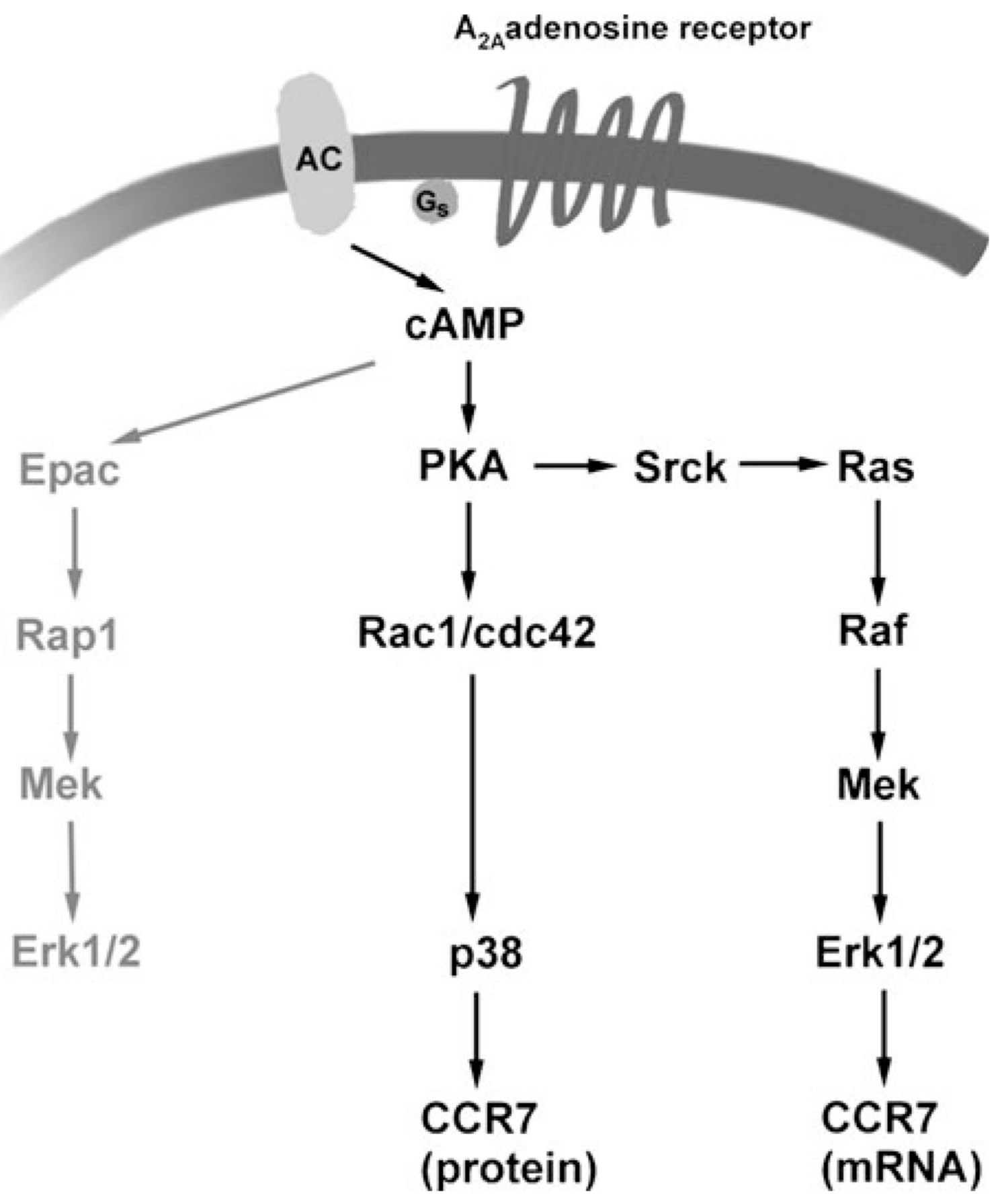

Fig. 6.

The $\mathrm{A}_{2 \mathrm{~A}}$ adenosine receptor uses signaling pathways downstream of PKA to regulate CCR7 expression. The $\mathrm{A}_{2 \mathrm{~A}}$ adenosine receptor subtype's G-stimulatory protein subunit $\left(G_{s}\right)$ activates adenylate cyclase $(A C)$, which leads to production of cAMP and stimulation of primarily $\mathrm{p} 38$ signaling to decrease CCR7 protein and primarily MA-PK signaling to increase CCR7 mRNA in THP1 macrophages. 